\title{
Sward structure and livestock performance in guinea grass cv. Tanzania pastures managed by rotational stocking strategies
}

\author{
Valéria Pacheco Batista Euclides ${ }^{1 *}$, Denise Bataglin Montagner ${ }^{1}$, Gelson dos Santos Difante ${ }^{2}$, Rodrigo Amorim Barbosa ${ }^{1}$, \\ Wellington Souza Fernandes ${ }^{1}$
}

${ }^{1}$ Embrapa Beef Cattle, Av. Radio Maia, 830 - 79106-550 Campo Grande, MS - Brazil.

${ }^{2}$ Federal University of Rio Grande do Norte - Dept. of Animal Science, C.P. 1524 - 59078-900 - Natal, RN - Brazil.

*Corresponding author <valeria.pacheco@embrapa.br>

Edited by: Gerson Barreto Mourão

Received August 23, 2013

Accepted April 10, 2014

\begin{abstract}
Grazing strategy is a key element in the determination of sward structure, herbage nutritive value and animal performance. We aimed to compare the herbage characteristics and performance of livestock in pastures of Panicum maximum cv. Tanzania managed, using two rotational stocking strategies, which provided either a fixed-length rest period (FRP) of 35 days in the spring and fall and 30 days in the summer, or a variable-length rest period (VRP), determined by the time required for the canopy to achieve $70 \mathrm{~cm}$ in height. The pastures were evaluated in the pregrazing condition for forage mass (FM); leaf (LP), stem (SP) and dead matter (DP) percentages; and nutritive value (NV). The animals were weighed every 28 days. Pastures managed with the FRPs exhibited greater FMs, SPs and DPs and lower LPs and NVs than those managed with the VRPs. The average daily livestock weight gain was greater during the spring and summer for the VRP than for the FRP pastures, resulting in an average animal weight gain per area of 990 and $860 \mathrm{~kg} \mathrm{ha}^{-1}$ wet period ${ }^{-1}$ for the pastures managed with the VRPs and FRPs, respectively. Thus, pasture rest periods that were maintained after the sward reached $70 \mathrm{~cm}$ in height reduced the animal performance on Tanzania guinea grass.

Keywords: Panicum maximum, canopy height, nutritive value, savannah, stocking rate
\end{abstract}

\section{Introduction}

In general, Panicum maximum cv. Tanzania (Tanzania guinea grass) has been managed under rotational grazing with fixed rest periods regardless of the season (Andrade et al., 2006) fertilization levels, (Lopes et al., 2013) and irrigation (Dupas et al., 2010). Management based on fixed and predetermined grazing and rest periods facilitates the planning of rotational grazing. However, Pedreira et al. (2007) observed inconsistent responses in Brachiaria brizantha cv Xaraes pastures when fixed rest periods were used, since, depending on the time of year and the prevailing growing conditions, these periods can be too short, leading to production losses in herbage, or too long which can result in loss of quantity and quality, as well as the degeneration of the canopy structure. Similar results were obtained by Barbosa et al., (2007) and Da Silva et al., (2009), who suggested that rest periods that are fixed and defined a priori for guinea grass pastures can restrict livestock production as these periods do not generate uniform plant physiological response patterns, resulting in variable sward structures.

The regrowth of Panicum maximum cv. Tanzania (Tanzania guinea grass) should be interrupted when the canopy is intercepting $95 \%$ of the incident light (LI), which corresponds to a sward height of $70 \mathrm{~cm}$ (Barbosa et al., 2007). Growth beyond this point promotes sward deterioration, characterized by higher percentages of stem and dead material, a lower percentage of leaf and a reduced leaf-to-stem ratio. As the steer diet consists primarily of leaf blades, the presence of sheath, stem and dead material at the grazing horizon limits the bite depth (Chacon and Stobbs, 1976). Under such conditions, it is common to observe an increase in the bite duration, a reduction of the bite rate (Palhano et al., 2007) and an increase in the daily grazing time (Difante et al., 2009), resulting in inefficient harvesting and, consequently, low animal performance (Da Silva et al., 2012).

In this study we compared the sward structure, nutritive value and animal performance in Tanzania guinea grass pastures subjected to two rotational stocking strategies, one with fixed and predefined grazing and rest periods (FRPs) and the other based on a target of 70 $\mathrm{cm}$ for pregrazing and canopy height, or to reduce the rest period during the summer to 30 days for pastures managed with the FRPs.

\section{Materials and Methods}

The experiment was conducted during the 2007 and 2008 growing seasons in Campo Grande, in the state of Mato Grosso do Sul, Brazil (20² $7^{\prime}$ S, 54 $37^{\circ}$ W, 530 $\mathrm{m}$ a.s.l.). According to the Köppen classification, the climate is rainy tropical savannah of the Aw subtype, which is characterized by a seasonal distribution of rainfall and well-defined occurrence of the dry period during the colder months. Monthly rainfall and the minimum, average and maximum temperatures during the study period were recorded at the Embrapa weather station (Figure 1), $5 \mathrm{~km}$ from the experimental site. The average temperature and monthly precipitation were used to calculate the water balance (Figure 2). The value used for the soil water storage capacity was $75 \mathrm{~mm}$.

The Tanzania guinea grass pastures were established on an Oxisol and fertilized with $80 \mathrm{~kg} \mathrm{ha}^{-1}$ of $\mathrm{P}_{2} \mathrm{O}_{5}, 80 \mathrm{~kg} \mathrm{ha}^{-1}$ of $\mathrm{K}_{2} \mathrm{O}$ and $200 \mathrm{~kg} \mathrm{ha}^{-1}$ of $\mathrm{N}$. The fertil- 


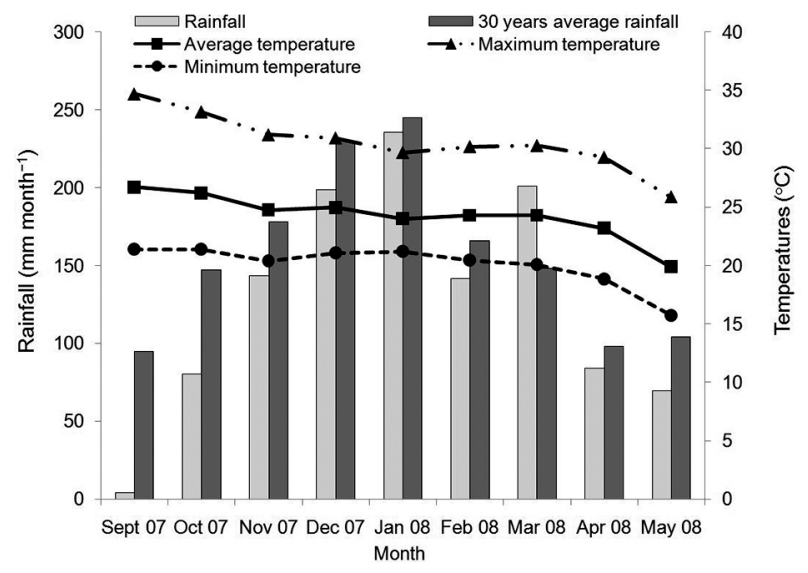

Figure 1 - Rainfall and maximum, average and minimum temperatures during the experimental period, and the historical 30-year average rainfall.

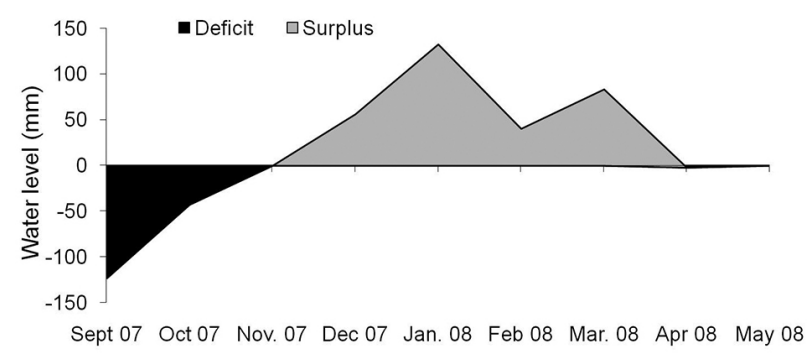

Month

Figure 2 - Water deficit and surplus in the soil during the experimental period, for a soil water holding capacity of $75 \mathrm{~mm}$.

izers were applied in Oct 2007, except for $\mathrm{N}$ that was divided into three applications, namely, Oct, Dec and Feb. Twelve modules each measuring 1.125 ha were divided into six paddocks of 0.188 ha each. A 12.0 ha-reserve pasture was also used for holding the put-and-take animals (the 'grazers') when they were not needed in the experimental units.

A randomized complete block experimental design was employed, with two treatments and six replicates. The treatments consisted of two strategies of rotational stocking as follows: one with fixed and predefined grazing and rest periods (FRP), of 7 and 35 days, during spring and autumn and 6 and 30 days in summer, respectively, and the other with a variable rest period associated with a pregrazing height of $70 \mathrm{~cm}$ (VRP), corresponding to the height at which the canopy intercepts $95 \%$ of the LI (Barbosa et al., 2007). Both treatments were associated with a common postgrazing height of $35 \mathrm{~cm}$.

Each experimental unit (module of six paddocks) was grazed by five Nellore tester steers, which were approximately 12 months of age when the experiment started and had an average initial weight of $290 \mathrm{~kg}$. The testers were assigned randomly to experimental units; differences in the allocation weight across treatments were not significant at the beginning of the rainy season, and the animals remained in the same paddock for the entire experimental period. Ninety 'grazer' steers similar to the tester steers in weight, age, background and breeding were kept in the reserve pasture and used where needed to adjust the stocking rate.

For the pastures managed with FRPs, the grazers were added to or removed from all the paddocks as determined by the pregrazing herbage mass (HM) and the predetermined postgrazing height $(35 \mathrm{~cm})$. For the pastures managed with the VRPs, the decision regarding the addition or removal of the grazers was based on the pregrazing HM, the postgrazing target and the need for the animals to remain in their current paddock (variable grazing period) until the canopy height in the next paddock to be grazed reached the pregrazing target $170 \mathrm{~cm}$ sward height; which corresponds $95 \%$ LI, Barbosa et al., 2007).

Throughout the regrowth period, the sward height of the pastures managed with the VRPs was monitored twice a week using a 1-m ruler graduated in centimeters to systematically perform the height measurements along five transect lines (ten measurement points per transect) in each paddock. The sward height measurements were taken from ground leaves based on the 'leaf horizon' on the top of the sward as a reference. This procedure was followed throughout the growing season, including the periods when the plants were reproductive and produced taller flowering stems. For those pastures managed with the FRPs, the sward height was only monitored when the grazing period started. The same procedure was used to determine the postgrazing height.

All pasture measurements were conducted in two paddocks for each module (experimental unit). The pre- and postgrazing herbage masses were determined from twelve samples per paddock. The herbage was cut at ground level using a $1-\mathrm{m}^{2}$ frame. Each sample was weighed and divided in two. One of the subsamples was oven dried at $65{ }^{\circ} \mathrm{C}$ and weighed, and the other was separated into leaf (leaf blades), stem (stems and leaf sheaths) and dead material before each was dried at 65 ${ }^{\circ} \mathrm{C}$ and weighed.

The herbage and the leaf accumulation rates were calculated as the difference between the current pregrazing and preceding postgrazing masses, considering the masses of the green (leaves and stems) or only the leaf portions, respectively, divided by the number of days between the pre- and postgrazing sampling times.

Two hand-plucked samples were taken from each paddock. The samples were oven dried, ground to pass through a $1-\mathrm{mm}$ screen and analyzed to obtain estimations of crude protein, neutral detergent fiber, acid detergent lignin and in vitro organic matter digestibility via near infrared reflectance spectrophotometry (NIRS) according to Marten et al. (1985).

All steers were weighed after fasting for $16 \mathrm{~h}$ at 28-day intervals. The average daily gain (ADG) was cal- 
culated as the difference between the liveweights of the testers divided by the number of days between the weight measurements. The stocking rate was calculated according to Petersen and Lucas (1968) as the product of the average liveweights of the tester and grazer steers and the number of days that these steers remained in the experimental unit. The liveweight gain per area was obtained by multiplying the ADG of the tester steers by the number of steers (testers and grazers) retained per module and per grazing cycle.

The data were grouped according to seasons of the year as follows: spring, 17 Oct to 19 Dec 2007; summer, 20 Dec 2007 to 19 Mar 2008; and autumn, 20 Mar to 20 May 2008. The data were subjected to an analysis of variance using the PROC MIXED in SAS (Statistical Analysis System, version 9.4). The applied model included the random effect of the blocks and the fixed effects of the management strategy, the season and the interaction between strategy and season. Where appropriate, the means were compared with Tukey's test $(p<0.05)$. The ADG data were analyzed via a multivariate analysis with repeated measures according to Littell et al. (2000). The correlation between sward height and herbage mass was estimated using the PROC CORR in SAS (Statistical Analysis System, version 9.4).

\section{Results}

The pregrazing sward heights remained within the planned range throughout the experiment, except for the first and last grazing cycles (Table 1) in pastures VRP. Regardless of the season, the postgrazing residue target was maintained close to the planned values (Table 1), resulting in similar ( $p=0.2102)$ herbage masses (HMs), which averaged $2870 \pm 83 \mathrm{~kg} \mathrm{ha}^{-1}$ of dry matter (DM).

The VRP pastures reached the pre-grazing target faster in the summer than in the other seasons $(p=$ 0.0001) (Table 2). Additionally, the grazing period (GP) was shorter in the summer than in the other seasons (Table 2). Except in autumn, the grazing and rest periods were shorter $(p=0.0001)$ for the pastures managed with the variable-length rest period (VRPs) than for those managed with the fixed and predefined grazing and rest periods (FRPs) (Table 2). There was interaction between management strategy and season for the herbage accumulation (HA, $p=0.0001$ ), the pregrazing $\mathrm{HM}$ $(p=0.0074)$, the leaf (LP, $p=0.0001)$ and stem (SP, $p$ $=0.0001)$ percentages, and the leaf-to-stem ratio (LSR, $p=0.0001)$.

Regardless of the management strategy, HA was greater in the summer than in the other seasons (Table 2). During spring and autumn, there was no difference in HA between the management strategies; however, in summer, HA was greater for the FRP pastures than for the VRP pastures (Table 2). The pregrazing HM was lower in the autumn than in the other seasons under both management strategies. The HM was higher in summer than in spring for the FRP pastures but did not differ between summer and spring for the VRP pastures (Table 2). By contrast, the HM was similar under both management strategies during autumn and spring but higher in summer for the FRP pastures than for the VRPs (Table 2).

Regardless of season, the FRP pastures presented lower LPs and higher SPs than the VRP (Table 2). The FRP pastures exhibited similar LPs and SPs throughout the growing season. By contrast, the VRP had higher LPs in summer and higher SPs in autumn when compared with the other seasons (Table 2). Except in autumn, the mean leaf-to-stem ratio (LSR) was lower for the FRP pastures (Table 2).

No seasonal effect ( $p=0.2683$ ) or management strategy by season interaction $(p=0.0944)$ was detected for the dead matter percentage (DP); however, the mean DP was higher for the FRP pastures than for the VRP (Table 3).

There was no interaction between management strategy and season for the herbage (HAR, $p=0.7612)$ and leaf (LAR; $p=0.2470$ ) accumulation rates. Moreover, no management strategy effect $(p=0.7820)$ was detected for the HAR; however, the VRP pastures exhibited a higher mean LAR than FRP (Table 3). Furthermore, both the mean HAR and LAR were highest in summer and lowest in autumn (Table 4).

At postgrazing, there was no interaction between management strategy and season $(p=0.0548)$ for the LP,

Table 1 - Means and standard deviations for the pre- and postgrazing sward heights of $P$. maximum cv. Tanzania pastures subjected to rotational stocking with fixed and variable rest periods by the initiation date of each grazing cycle.

\begin{tabular}{|c|c|c|c|c|c|}
\hline \multicolumn{3}{|c|}{ Fixed rest period } & \multicolumn{3}{|c|}{ Variable rest period } \\
\hline \multirow[b]{2}{*}{ Date } & \multicolumn{2}{|c|}{ Height $(\mathrm{cm})$} & \multirow[b]{2}{*}{ Date } & \multicolumn{2}{|c|}{ Height $(\mathrm{cm})$} \\
\hline & Pregrazing & Postgrazing & & Pregrazing & Postgrazing \\
\hline $10 / 17 / 07$ & $58.1 \pm 6.0$ & $33.1 \pm 1.1$ & $10 / 17 / 07$ & $60.9 \pm 5.9$ & $34.9 \pm 2.2$ \\
\hline $11 / 28 / 07$ & $77.7 \pm 3.9$ & $34.8 \pm 1.2$ & $11 / 22 / 07$ & $70.5 \pm 1.9$ & $36.2 \pm 1.9$ \\
\hline $01 / 09 / 08$ & $87.1 \pm 5.5$ & $38.6 \pm 2.6$ & $12 / 21 / 07$ & $72.3 \pm 1.1$ & $37.8 \pm 2.8$ \\
\hline $02 / 14 / 08$ & $92.0 \pm 9.6$ & $39.7 \pm 2.7$ & $01 / 16 / 08$ & $71.6 \pm 1.7$ & $36.0 \pm 1.6$ \\
\hline 03/23/08 & $78.8 \pm 5.3$ & $37.6 \pm 2.9$ & $02 / 14 / 08$ & $70.8 \pm 1.4$ & $36.4 \pm 1.2$ \\
\hline $05 / 01 / 08^{A}$ & $66.2 \pm 4.3$ & $36.1 \pm 1.8$ & $03 / 18 / 08$ & $68.5 \pm 1.9$ & $35.7 \pm 2.3$ \\
\hline- & - & - & $04 / 23 / 08^{B}$ & $66.5 \pm 2.8$ & $33.5 \pm 2.5$ \\
\hline
\end{tabular}

${ }^{\mathrm{A} O n l y}$ three paddocks of each module were grazed; ${ }^{B}$ Only four paddocks of each module were grazed. 
Table 2 - Mean rest and grazing period durations, herbage accumulation, pregrazing herbage mass, leaf, and stem percentages, and leaf to stem ratio of $P$. maximum cv. Tanzania pastures subjected to rotational grazing with fixed and variable rest periods from 0ct 2007 to May 2008.

\begin{tabular}{|c|c|c|c|}
\hline Rest period & Spring & Summer & Autumn \\
\hline \multicolumn{4}{|c|}{ Rest period (days) } \\
\hline Fixed & 35 & 30 & 35 \\
\hline Variable & $\begin{array}{l}29 a \\
(0.6)\end{array}$ & $\begin{array}{l}23 \mathrm{~b} \\
(0.5)\end{array}$ & $\begin{array}{l}31 \mathrm{a} \\
(0.6)\end{array}$ \\
\hline \multicolumn{4}{|c|}{ Grazing period (days) } \\
\hline Fixed & 7.0 & 6.0 & 7.0 \\
\hline Variable & $\begin{array}{l}5.8 \mathrm{a} \\
(0.2)\end{array}$ & $\begin{array}{l}4.6 \mathrm{~b} \\
(0.1) \\
\end{array}$ & $\begin{array}{l}6.2 \mathrm{a} \\
(0.4) \\
\end{array}$ \\
\hline \multicolumn{4}{|c|}{ Herbage accumulation (kg ha ${ }^{-1}$ grazing cycle ${ }^{-1}$ dry matter) } \\
\hline Fixed & $\begin{array}{c}1,840 \mathrm{Ab} \\
(111)\end{array}$ & $\begin{array}{c}3,030 \mathrm{Aa} \\
(86)\end{array}$ & $\begin{array}{c}1,360 \mathrm{Ab} \\
\text { (123) }\end{array}$ \\
\hline Variable & $\begin{array}{c}1,600 \mathrm{Ab} \\
(104)\end{array}$ & $\begin{array}{c}2,230 \mathrm{Ba} \\
(84)\end{array}$ & $\begin{array}{c}1,350 \mathrm{Ab} \\
\text { (89) }\end{array}$ \\
\hline \multicolumn{4}{|c|}{ Herbage mass (kg ha-1 dry matter) } \\
\hline Fixed & $\begin{array}{c}5,160 \mathrm{Ab} \\
(389)\end{array}$ & $\begin{array}{c}\text { 6,790 Aa } \\
\text { (332) }\end{array}$ & $\begin{array}{c}4,950 \mathrm{Ac} \\
(407)\end{array}$ \\
\hline Variable & $\begin{array}{c}4,950 \mathrm{Aa} \\
(341)\end{array}$ & $\begin{array}{c}5,370 \mathrm{Ba} \\
(314)\end{array}$ & $\begin{array}{c}4,250 \mathrm{Ab} \\
(414)\end{array}$ \\
\hline \multicolumn{4}{|c|}{ Leaf (\%) } \\
\hline Fixed & $\begin{array}{c}62.2 \mathrm{Ba} \\
(1.3)\end{array}$ & $\begin{array}{c}60.3 \mathrm{Ba} \\
(1.1)\end{array}$ & $\begin{array}{c}64.3 \mathrm{Ba} \\
(1.4)\end{array}$ \\
\hline Variable & $\begin{array}{c}\text { 72.4 Ab } \\
(1.3)\end{array}$ & $\begin{array}{c}79.0 \mathrm{Aa} \\
(0.9)\end{array}$ & $\begin{array}{c}71.6 \mathrm{Ab} \\
(1.1)\end{array}$ \\
\hline \multicolumn{4}{|c|}{ Stem (\%) } \\
\hline Fixed & $\begin{array}{c}17.9 \mathrm{Aa} \\
(0.7)\end{array}$ & $\begin{array}{c}21.4 \mathrm{Aa} \\
(0.6)\end{array}$ & $\begin{array}{c}\text { 18.6 Aa } \\
(0.8)\end{array}$ \\
\hline Variable & $\begin{array}{c}13.2 \mathrm{Bb} \\
(0.7)\end{array}$ & $\begin{array}{c}12.0 \mathrm{Bb} \\
(0.5)\end{array}$ & $\begin{array}{c}16.6 \mathrm{Ba} \\
(0.6)\end{array}$ \\
\hline \multicolumn{4}{|c|}{ Leaf to stem ratio } \\
\hline Fixed & $\begin{array}{c}3.5 \mathrm{Ba} \\
(0.3)\end{array}$ & $\begin{array}{c}2.8 \mathrm{Ba} \\
(0.2)\end{array}$ & $\begin{array}{c}3.5 \mathrm{Aa} \\
(0.4)\end{array}$ \\
\hline Variable & $\begin{array}{c}5.5 \mathrm{Aa} \\
(0.2)\end{array}$ & $\begin{array}{c}6.6 \mathrm{Aa} \\
(0.2)\end{array}$ & $\begin{array}{c}4.3 \mathrm{Ab} \\
(0.3)\end{array}$ \\
\hline
\end{tabular}

Means followed by the same lowercase letter within rows or means followed by the same uppercase letter in the same column, do not differ $(p>0.05)$ by Tukey's test; values in parentheses are standard errors of the difference.

Table 3 - Pregrazing means, standard errors of the difference (s.e.d.) and probability levels $(p)$ for leaf accumulation rate (LAR), dead material percentage (DP) and acid detergent lignin (ADL) content of P. maximum cv. Tanzania pastures subjected to rotational grazing from Oct 2007 to May 2008.

\begin{tabular}{|c|c|c|c|c|}
\hline & \multicolumn{2}{|c|}{ Rest period } & \multirow[b]{2}{*}{ s.e.d. } & \multirow[b]{2}{*}{$p$} \\
\hline & fixed & variable & & \\
\hline LAR $\left(\mathrm{kg} \mathrm{ha}^{-1} \mathrm{~d}^{-1}\right)$ & 48.3 & 55.3 & 1.9 & 0.0084 \\
\hline $\mathrm{DP}(\%)$ & 18.4 & 11.7 & 1.1 & 0.0001 \\
\hline ADL (\%) & 3.1 & 2.8 & 0.04 & 0.0065 \\
\hline
\end{tabular}

SP or DP. Moreover, no management strategy effect was detected for the LP $(p=0.7852)$, SP $(p=0.3729)$ or DP $(p=0.5717)$, which averaged $25.9 \pm 0.5 \%, 28.5 \pm 0.6$ $\%$ and $45.6 \pm 0.8 \%$, respectively. No seasonal effect was found for the SP $(p=0.2206)$ or the DM $(p=0.1132)$. However, the mean LP was highest $(p=0.0009)$ in the summer $(28.2 \%)$ compared with the spring $(25.3 \%)$ and autumn (24.4\%). In the pregrazing sward, an interaction between management strategy and season was detected for the crude protein $(\mathrm{CP}, p=0.0001)$, the neutral detergent fiber (NDF, $p=0.0122)$ content and the in vitro organic matter digestibility (IVOMD, $p=0.0003$ ) but not for the acid detergent lignin (ADL, $p=0.0530$ ).

During summer, the VRP pastures had higher $\mathrm{CP}$ contents and IVOMDs as compared with the FRPs. Higher NDF contents were observed for the pastures managed with the FRPs during spring and summer (Table 5). Lower CP and IVOMD values and higher NDF contents were observed in autumn for the VRP pastures and in summer for the FRPs (Table 5).

Overall, a higher ADL content was observed for the FRP pastures than for those managed with the VRP (Table 3). Regardless of management strategy, the mean ADL content was higher during the autumn than during the other seasons (Table 4). There was interaction between management strategy and season for the stock- 
ing rate $(\mathrm{SR}, p=0.0302)$ and for the average daily gain (ADG, $p=0.0001$ ). The highest mean SR was observed during summer for both management strategies (Table 6). During the summer only, the mean SR was higher for the FRP pastures than for the VRPs (Table 6).

During spring and summer, greater ADGs were observed for the VRP pastures than for the FRPs; however, the two management strategies produced similar ADGs in autumn (Table 6). Furthermore, the FRP pastures exhibited a greater ADG mean in the spring than in the other seasons; however, for the VRP pastures, a lower ADG mean was observed in autumn than in the other seasons (Table 6). The higher SR observed in summer for the FRP pastures did not offset the lower individual liveweight gain (Table 6$)$, resulting in a higher $(p=0.0433)$ animal weight gain per area for the pastures managed with the VRPs than for the FRPs, which averaged 990 and $860 \pm 39 \mathrm{~kg} \mathrm{ha}^{-1}$ growth season ${ }^{-1}$, respectively.

Table 4 - Pregrazing means and probability levels ( $p$ ) for herbage (HAR) and leaf accumulation rates (LAR), dead material percentage (DP), and acid detergent lignin (ADL) content in P. maximum cV. Tanzania pastures subjected to rotational grazing with fixed and variable rest periods.

\begin{tabular}{|c|c|c|c|c|}
\hline & Spring & Summer & Autumn & $p$ \\
\hline HAR (kg ha-1 $\left.\mathrm{d}^{-1}\right)$ & $\begin{array}{c}62.6 \mathrm{~b} \\
(4.3)\end{array}$ & $\begin{array}{c}96.9 \mathrm{a} \\
(3.0)\end{array}$ & $\begin{array}{c}45.9 \mathrm{c} \\
(4.1)\end{array}$ & 0.0001 \\
\hline LAR $\left(\mathrm{kg} \mathrm{ha}^{-1} \mathrm{~d}^{-1}\right)$ & $\begin{array}{c}44.3 \mathrm{~b} \\
(2.3)\end{array}$ & $\begin{array}{c}77.7 \mathrm{a} \\
(1.8)\end{array}$ & $\begin{array}{c}33.3 \mathrm{c} \\
(2.3)\end{array}$ & 0.0001 \\
\hline DP (\%) & $\begin{array}{c}17.2 \mathrm{a} \\
(0.8)\end{array}$ & $\begin{array}{c}13.6 \mathrm{~b} \\
(0.6)\end{array}$ & $\begin{array}{c}14.4 \mathrm{~b} \\
(0.8)\end{array}$ & 0.0030 \\
\hline ADL (\%) & $\begin{array}{l}2.9 \mathrm{~b} \\
(0.08)\end{array}$ & $\begin{array}{l}3.0 \mathrm{~b} \\
(0.06)\end{array}$ & $\begin{array}{c}3.3 a \\
(0.07)\end{array}$ & 0.0001 \\
\hline
\end{tabular}

Means within rows followed by the same letter do not differ $(p>0.05)$ by Tukey's test; values in parentheses are standard errors of the difference.

Table 5 - Pregrazing means for crude protein, neutral detergent fiber content and in vitro organic matter digestibility for $P$. maximum cv. Tanzania pastures subjected to rotational grazing with fixed and variable rest periods from Oct 2007 to May 2008.

\begin{tabular}{lccc}
\hline Rest period & Spring & Summer & Autumn \\
\hline Crude protein (\%) & \multicolumn{3}{c}{} \\
\hline \multirow{2}{*}{ Fixed } & $14.0 \mathrm{Aa}$ & $11.3 \mathrm{Bb}$ & $13.0 \mathrm{Aa}$ \\
& $(0.3)$ & $(0.2)$ & $(0.3)$ \\
Variable & $15.0 \mathrm{Aa}$ & $15.6 \mathrm{Aa}$ & $13.5 \mathrm{Ab}$ \\
& $(0.3)$ & $(0.2)$ & $(0.3)$ \\
\hline Neutral detergent fiber (\%) & \multicolumn{3}{c}{} \\
\hline \multirow{2}{*}{ Fixed } & $75.3 \mathrm{Aa}$ & $75.9 \mathrm{Aa}$ & $75.1 \mathrm{Aa}$ \\
& $(0.6)$ & $(0.6)$ & $(0.6)$ \\
Variable & $72.3 \mathrm{Bb}$ & $71.8 \mathrm{Bb}$ & $74.5 \mathrm{Aa}$ \\
& $(0.5)$ & $(0.4)$ & $(0.5)$ \\
\hline In vitro organic matter digestibility (\%) & \multicolumn{3}{c}{} \\
Fixed & $64.6 \mathrm{Aa}$ & $61.1 \mathrm{Bb}$ & $62.4 \mathrm{Aab}$ \\
& $(0.8)$ & $(0.8)$ & $(0.8)$ \\
Variable & $67.8 \mathrm{Aa}$ & $68.2 \mathrm{Aa}$ & $63.2 \mathrm{Ab}$ \\
& $(0.6)$ & $(0.8)$ & $(0.7)$ \\
\hline
\end{tabular}

Means followed by the same lowercase letter within rows or means followed by the same uppercase letter in the same column, do not differ $(p>0.05)$ by Tukey's test; values in parentheses are standard errors of the difference.

\section{Discussion}

During the dry period preceding the beginning of the experiment, the pastures were grazed to maintain the postgrazing height of $35 \mathrm{~cm}$. Despite the welldefined dry period from May to Sept, optimal weather conditions for the growth of $P$. maximum cv. Tanzania were not restored until mid-November 2009 (Figures 1 and 2). However, in practical terms, the beginning of the rainy season coincides with low forage availability throughout the property and, in general, the producer has difficulty reallocating the animals to adequate pastures, making it necessary to use pastures as soon as they start recovering (Difante et al., 2009). For this reason, and because the two strategies were evaluated over the same interval, we decided to initiate grazing after the sward in the paddocks of each module had first reached an average height of approximately $50 \mathrm{~cm}$, i.e., less than the targeted pregrazing height $(70 \mathrm{~cm})$. At this stage, $\mathrm{P}$ and $\mathrm{K}$ fertilization was applied, followed by the first $\mathrm{N}$ application. This procedure resulted in a pregrazing height that was below the target for the first grazing cycle in the VRP pastures (Table 1). By contrast, the below-target pregrazing heights for the cycles performed during Apr and May could be explained by the HARs reaching their lowest values in autumn (Table 4), a consequence of the water deficit recorded from Apr (Figure 2).

Except in autumn, the pregrazing target $(70 \mathrm{~cm})$ was reached faster than the fixed and predefined rest periods (Table 2), which resulted one more grazing cycle in the VRP than in the FRP treatment group (Table 1) and could be a consequence of the higher HARs in spring and summer (Table 4). This result may be explained by the more favorable spring and summer climatic conditions (Figures 1 and 2) and the application of $1 / 3$ or $2 / 3$ of the $N$ fertilizer by spring or summer, respectively.

Table 6 - Means for stocking rate and average daily gain in $P$. maximum cv. Tanzania pastures subjected to rotational grazing with fixed and variable rest periods from Oct 2007 to May 2008.

\begin{tabular}{lccc}
\hline Rest period & Spring & Summer & Autumn \\
\hline Stocking rate $\left(\mathrm{AU}^{*} \mathrm{ha}^{-1}\right)$ & & & \\
\hline \multirow{2}{*}{ Fixed } & $4.0 \mathrm{Ab}$ & $7.7 \mathrm{Aa}$ & $4.1 \mathrm{Ab}$ \\
& $(0.3)$ & $(0.3)$ & $(0.4)$ \\
Variable & $3.4 \mathrm{Ab}$ & $5.8 \mathrm{Ba}$ & $3.8 \mathrm{Ab}$ \\
& $(0.3)$ & $(0.3)$ & $(0.4)$ \\
\hline
\end{tabular}

Average daily gain $\left(\mathrm{kg}_{\text {animal }}{ }^{-1} \mathrm{~d}^{-1}\right)$

\begin{tabular}{lccc}
\hline Fixed & $700 \mathrm{Ba}$ & $630 \mathrm{Ba}$ & $640 \mathrm{Ab}$ \\
& $(26)$ & $(21)$ & $(26)$ \\
Variable & $870 \mathrm{Aa}$ & $830 \mathrm{Aa}$ & $650 \mathrm{Ab}$ \\
& $(26)$ & $(21)$ & $(26)$
\end{tabular}

${ }^{*} \mathrm{AU}=450 \mathrm{~kg}$ liveweight; Means followed by the same lowercase letter within rows or means followed by the same uppercase letter in the same column, do not differ $(p>0.05)$ by Tukey's test; values in parentheses are standard errors of the difference. 
Similar HAR values $\left(68 \mathrm{~kg} \mathrm{ha}^{-1} \mathrm{~d}^{-1}\right)$ were recorded under both management strategies. However, the higher LAR mean observed under the VRP than the FRP strategies (Table 3) is in agreement with other studies (Carnevalli et al., 2006; Barbosa et al., 2007; Da Silva et al., 2009) in which the maximum net leaf accumulation for guinea grass was obtained when the canopy was intercepting $95 \%$ of the incident radiation. Moreover, Barbosa et al. (2007) found that 95 and $100 \%$ light interception corresponded with canopy heights of 70 and 85 $\mathrm{cm}$ for Tanzania guinea grass, respectively. Based on this information, the process of regrowth was interrupted for the FRP treatment group (Table 1) when the canopy intercepted more than $95 \%$ of the incident radiation.

In general, the prolongation of the rest period along with the interception by the canopy of $95 \%$ of the incident light, which for Tanzania guinea grass corresponds to a $70 \mathrm{~cm}$ canopy height, resulted in a higher HM pregrazing (Table 2). However, this increase was primarily from the accumulation of stems (Table 2) and dead material (Table 3) because there was no difference $(p=0.1593)$ between management strategies in the pregrazing leaf lamina mass $\left(3300 \pm 144 \mathrm{~kg} \mathrm{ha}^{-1}\right.$ of DM). Note that negative correlations were observed between the canopy height and the stem mass $\left(p=0.0001, \mathrm{r}^{2}=\right.$ 0.80 ) and between the canopy height and the mass of dead material ( $p=0.0001, \mathrm{r}^{2}=0.69$ ). The interruption of regrowth at canopy heights greater than $70 \mathrm{~cm}$ promoted higher percentages of stem and dead material and a lower leaf percentage and leaf-to-stem ratio (Tables 2 and 3). It is probable that these circumstances contributed to an increased difficulty grazing, resulting in lower ADGs during spring and summer for the FRP pastures (Table 6). This result is consistent with the observation made by Chacon and Stobbs (1976) that the presence of stem and dead material at the grazing horizon limits the bite depth. Under such conditions, it is common to observe an increase in the bite duration, a reduction in the bite rate (Palhano et al., 2007) and an increase in the daily grazing time (Difante et al., 2009), which all influence nutrient intake and thus, animal performance (Da Silva et al., 2012).

The greater pregrazing HA mean observed for the FRP pastures during summer (Table 2) could be explained by the longer rest period imposed on those pastures (Table 2). Consequently, a higher stocking rate (SR) was also necessary in the summer to maintain the postgrazing height target (Table 6) for the FRP pastures. The longer rest period may additionally explain the lower CP and IVOMD percentages (Table 5) and the lower ADG (Table 6) for the FRP pastures during summer. The decreased nutritive value and $\mathrm{ADG}$ as the rest period increased were also observed by Cândido et al. (2005) for guinea grass pasture.

The changes in the grazing period for the VRP pastures (Table 2) could be explained by the variation in the HARs (Table 4), the decisions regarding the SR adjustments necessary to maintain the postgrazing tar- get (Figure 3) and the need for the animals to remain in their current paddock until the next paddock to be grazed reached the pregrazing target. Consequently, the SR was higher in summer for the VRP pastures (Table 6).

Regardless of the management strategy, the steer liveweight increased steadily over the growth season (Figure 3). The animals grazing the FRP pastures had similar ADGs throughout the growth season (Table 6). By contrast, for the VRP pastures, the ADG in autumn was lower than in the other seasons (Table 6) because of the autumn declines of the sward LSR (Table 2) and forage nutritive value (Tables 4 and 5). The structural sward variation in autumn could be partly explained by the flowering of $P$. maximum cv. Tanzania, which occurs during mid-April in Campo Grande (latitude $20^{\circ} 27^{\prime}$ S). After the emergence of the inflorescence the leaf appearance ceases, stem elongation and dead material accumulation increase. Additionally, the decrease in the nutritive value of tropical pastures during the reproductive phase was observed by Minson (1990).

The number of extra animals (1.9 $\left.\mathrm{AU} \mathrm{ha}^{-1}\right)$ used in the pastures managed with the FRP pastures during summer did not offset the lower individual liveweight gain (Table 6), resulting in lower liveweight gain per area (WGA). Thus, the shorter rest period during summer was ineffective for grazing management because this reduction was unable to control the sward structure and consequently the herbage nutritive value. In contrast, the use of the pregrazing canopy height to define the intervals between successive grazing periods dealt effectively with this variability. Thus, the WGA difference of $130 \mathrm{~kg}$ $\mathrm{ha}^{-1}$ during the growth period justified the monitoring of the pasture heights, the reduction of the rest period (Table 2) and the adjustments in the stocking rate (Figure 3) that were required to maintain the target-based grazing management, especially during the months of greatest pasture growth.

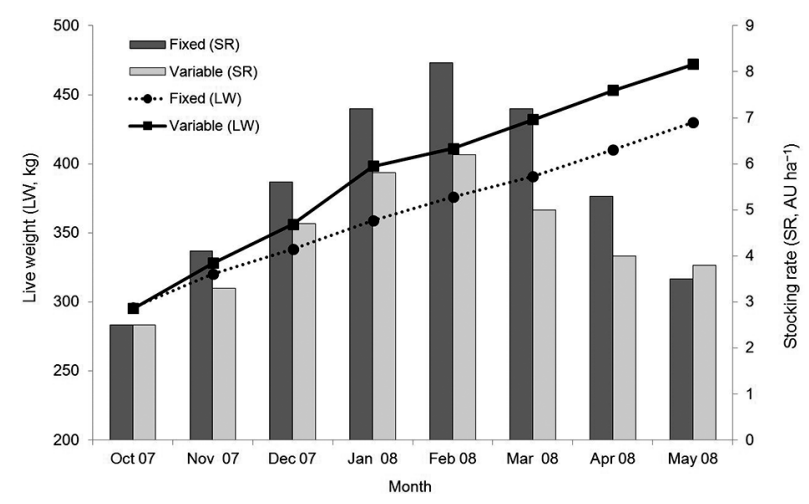

Figure 3 - Monthly distribution of steer liveweights and stocking rates on $P$. maximum cv. Tanzania pastures under rotational stocking with fixed and variable rest periods from Oct 2007 to May 2008. 


\section{Conclusions}

The use of a plant-growth based criterion like sward height to define intervals between successive grazing periods results in better control of sward structure and herbage nutritive value. Intervals between successive grazing periods greater than those needed for the canopy of Panicum maximum cv. Tanzania to reach $70 \mathrm{~cm}$ result in reduced animal performance and consequently, in lower yield per area. Thus, the greater animal productivity justified the monitoring of the pasture heights, the reduction of the rest period and the adjustments in the stocking rate that were required to maintain the target-based grazing management.

\section{Acknowledgements}

To FUNDECT (Mato Grosso do Sul State Foundation for Education, Science and Technology Development) and to $\mathrm{CNPq}$ (Brazilian National Council for Scientific and Technological Development) for partial funding of this research.

\section{References}

Andrade, C.M.S; Garcia, R.; Valentim, J.F.; Pereira, O.G. 2006. Grazing management strategies for massaigrass-forage peanut pasture. 2. Productivity, utilizatiom and sward structure. Revista Brasileira de Zootecnia 35: 343-351.

Barbosa, R.A.; Nascimento Júnior, D.; Euclides, V.P.B.; Da Silva, S.C.; Zimmer, A.H.; Torres Jr., R.A.A. 2007. Tanzania grass subjected to combinations of intensity and frequency of grazing. Pesquisa Agropecuária Brasileira 31: 329-340 (in Portuguese, with abstract in English).

Cândido, M.J.D.; Alexandrino, E.; Gomide, C.A.M.; Gomide, J.A.; Pereira, W.E. 2005. Rest period, forage nutritive value and steers performance on Panicum maximum cv. Mombaça pasture under intermitente stocking. Revista Brasileira de Zootecnia 34: 1459-1467 (in Portuguese, with abstract in English).

Carnevalli, R.A.; Da Silva, S.C.; Bueno, A.A.O.; Uebele, M.C.; Hodgson, J.; Da Silva, G.N.; Morais, J.P.G. 2006. Herbage production and grazing losses in Panicum maximum cv. Mombaça under four grazing managements. Tropical Grasslands 40: 165176.

Chacon, E.; Stobbs, T.H. 1976. Influence of progressive defoliation of a grass sward on the eating behaviour of cattle. Australian Journal of Agricultural Research 27: 709-727.

Da Silva, S.C.; Bueno, A.A.O.; Carnevalli, R.A.; Uebele, M.C.; Bueno, F.O.; Hodgson, J.; Matthew, C.; Arnold, G.C.; Morais, J.P.G. 2009. Swars structural characteristics and herbage accumulation of Panicum maximum cv. Mombaça subjected to rotational stocking managements. Scientia Agricola 66: 8-19.
Da Silva, S.C.; Gimenes, F.M.A.; Sarmento, D.O.L.; Sbrissia, A.F.; Oliveira, D.E; Hernandez-Garay, A.; Pires, A.V. 2012. Grazing behaviour, herbage intake and animal performance of beef cattle heifers on marandu palisade grass subjected to intensities of continuous stocking management. Journal of Agricutural Science 151: 727-739.

Difante, G.S.; Euclides, V.P.B.; Nascimento Jr., D.; Da Silva, S.C; Torres Jr., A.A.R; Sarmento, D.O.L. 2009. Ingestive behaviour, herbage intake and grazing efficiency of beef cattle steers on Tanzania guineagrass subjected to rotational stocking managements. Revista Brasileira de Zootecnia 38: 1001-1008.

Dupas, E.; Buzetti, S.; Sarto, A.L.; Hernandez, F.B.T.; Bergamaschine, A.F. 2010. Dry matter yield and nutritional value of marandu grass under nitrogen fertilization and irrigation in Cerrado in São Paulo. Revista Brasileira de Zootecnia 39: 2598-2603.

Littell, R.C.; Pendergast, J.; Natarajan, R. 2000. Modelling covariance structure in the analysis of repeated measures data. Statistics in Medicine 19: 1793-1819.

Lopes, M.N.; Cândido, M.J.D.; Pompeu, R.C.F.F.; Da Silva, R.G.; Carvalho, T.C.F.; Sombra, W.A.; Morais Neto, L.B.; Peixoto, M.J.A. 2013. Biomass flow in massai grass fertilized with nitrogen under intermittent stocking grazing with sheep. Revista Brasileira de Zootecnia 42: 13-21.

Marten, G.C.; Shenk, J.S.; Barton, F.E. 1985. Near Infrared Reflectance Spectroscopy (NIRS): Analysis of Forage Quality. USDA, Washington, DC, USA. (Agriculture Handbook, 643).

Minson, D.J. Forage in Ruminant Nutrition. 1990. Academic Press, San Diego, CA, USA.

Palhano, A.L.; Carvalho, P.C.F.; Dittrich, J.R.; Moraes, A.; Da Silva, S.C.; Monteiro, A.L.G. 2007. Forage intake characteristics on mombaça grass pastures grazed by Holstein heifers. Revista Brasileira de Zootecnia 36: 1014-1021 (in Portuguese, with abstract in English).

Pedreira, B.C.; Pedreira, C.G.S.; Da Silva, S.C. 2007. Sward structure and herbage accumulation in Brachiaria brizantha cultivar Xaraés in response to strategies of grazing. Pesquisa Agropecuária Brasileira 42: 281-287 (in Portuguese, with abstract in English).

Petersen, R.G.; Lucas Jr., H.L. 1968. Computing methods for the evaluation of pastures by means of animal response. Agronomy Journal 60: 682-687. 